\title{
INSTITUTITONS AND ECONOMIC DEVELOPMENT - THEORETICAL PERSPECTIVE OF MISSED INSTITUTIONAL SUPPORT IN THE REPUBLIC OF CROATIA
}

Summary: $\quad$ The activities of institutions have proven to be extremely important in achieving the economic growth and development of national economies. In addition, observed imbalances within the national economy can be minimized due to the contribution of institutions. Therefore, it is necessary to detect opportunities and activities that could, due to adequate institutional implementation, promote the development of a certain area. In the Republic of Croatia, in general, there is a low level of stimulating environment for small and medium sized enterprises as one of the economy drivers. Besides, the parts of the Republic of Croatia in which the primary sector predominates are generally much less developed (for instance, counties of Eastern Croatia).

The aim of this paper is to examine the role and importance of institutions on economic development. In addition, it aims at detecting and describing the institutional obstacles in promotion of small and medium enterprises as well as in presenting the selected examples of missed institutional promotion within the primary sector, as an economic branch most represented in the parts of the Republic of Croatia whose development is much lower than the average or even the lowest. The paper predominantly uses theoretical descriptive methods with additional data given in order to confirm mentioned obstacles within the small and medium enterprises and primary sector.

Keywords: $\quad$ institutions, economic development, primary sector, Republic of Croatia

\footnotetext{
* $\quad$ Katarina Marošević, PhD, Assistant Professor, Faculty of Law, Josip Juraj Strossmayer University of Osijek, S. Radića 13, 31000 Osijek, Republic of Croatia. E-mail address: katarina.marosevic@pravos.hr. ORCID: https://orcid.org/0000-0002-8727-130X.

** Lorela Vukovac, LLM. E-mail address: lorela.vukovac@gmail.com. ORCID: https://orcid.org/0000-0001-7872-1308.
} 


\section{INTRODUCTION}

The question of the functioning of institutions and their importance for achieving profit in the national economy is very important. The basic motive for the operation of institutions, which includes both private and business activity, includes facilitating the daily life of citizens, as well as creating a motivating business environment and provided adequate institutional support. Therefore, the aim of this paper is to examine the importance of institutions in promoting development with emphasis on the main obstacles within the small and medium enterprises and give an overview of obstacles to the development of primary sector in the Republic of Croatia - bearing in mind that the geographical areas with predominance of primary sector are mostly the ones that are below the average level of national economic development, or even the most underdeveloped. Counties of Eastern Croatia - Brod Posavina County, Osijek - Baranya County, Požega - Slavonia County, Virovitica - Podravina County, Vukovar - Sryem County - are taken into consideration since four out of five of them are at the end of development list according to the development index ${ }^{1}$ measured by the Ministry of Regional Development and European Union Funds. The analysis of key problems related to institutions seeks to show the level and quality of institutional support provided to small and medium-sized enterprises and family farms.

After introductory remarks, the second chapter seeks to define the concept of institutions from different perspectives, taking into account the institutions we define as a set of rules, but also the perspective of institutions as an integral part of public administration. The same chapter connects institutions with the concept of economic development, listing some of the possibilities of measuring the quality of institutions. Economic theory has produced several measures of the quality of the work of institutions, the most important of which are the Citizen Participation Index, the Government Orientation Index, the Social Development Index, the Gini Coefficient and the Human Development Index. As the Gini coefficient is used to show the differences between the economic power of citizens, it is also easy to use in order to see possible differences within society. Given that one of the fundamental tasks of institutions is to mitigate differences in society and create a balanced living atmosphere, the Gini coefficients in this context can be viewed from the perspective of measuring institutional quality. The third chapter of this paper presents institutional support for small and medium enterprises in the Republic of Croatia and selects five categories that need to be corrected to enable progress and economic growth - corruption, politicization of institutions, tax burdens, administrative barriers and legal uncertainty. Chapter four of the paper takes into account the institutional support recorded by examples from the primary economic sector. The motivation for such a choice for analysis stems from the fact that the area with the highest representation of the primary sector a little over a quarter of a century ago was known as an extremely developed area of the Republic of Croatia, and even then, with a strong primary sector (counties of Eastern Croatia). From this, the important role of the primary sector is clear as the basis for the development of a large number of activities from other economic sectors. The raw material produced within the primary sector is the basis of a whole range of other activities - process-

1 Vrijednosti indeksa razvijenosti i pokazatelja za izračun indeksa razvijenosti 2018 (Ministarstvo regionalnog razvoja i fondova Europske unije, 5 January 2018) <https://razvoj.gov.hr/o-ministarstvu/djelokrug-1939/regionalni-razvoj/indeks-razvijenosti/ vrijednosti-indeksa-razvijenosti-i-pokazatelja-za-izracun-indeksa-razvijenosti-2018/3740> accessed 21 April 2021. 
ing, tourism, catering, trade. Destroyed production of the primary sector has led parts of the national economy of the Republic of Croatia (referring to counties of Eastern Croatia) to extremely low levels of development according to numerous economic indicators. Given that this is a geographical area that, in addition to economic hardship, also had to deal with the consequences of war, it is obvious that the role of institutions in such cases is even more important.

Institutional support was provided from the aspect of family farms as an important segment in the development of the primary sector. This reflects the link with the already mentioned central part of the work dealing with institutional support to small and medium enterprises. In addition to the theoretical approach, it provides additional relevant data. At the end of the paper, concluding remarks on the importance of adequate functioning of institutions are given.

\section{INSTITUTIONS AND ECONOMIC DEVELOPMENT}

\subsection{DEFINITION OF INSTITUTIONS: DIFFERENT PERSPECTIVES}

Scientific literature on economic topics is increasingly rich in research related to institutions and institutional support. The interest of researchers and the professional public has increased with the realization that in global socio-economic processes the success of each observed subject depends on the process of institutional adjustment. ${ }^{2}$ There is a lack of complete consensus on the meaning of the word "institution". Among the most relevant definitions is that of Nobel laureate in economics Douglass C. North, according to whom an institution is considered "a code of conduct in a particular society, or more formally, a constraint invented by man to shape human interactions, resulting in reduced insecurity in everyday life and business, that is structuring the political, economic and social interaction of people." ${ }^{3}$ In this regard, institutions represent "formally ${ }^{4}$ defined rules according to which economic interactions of economic entities take place with the aim of reducing uncertainty in these interactions and enabling decision-making in predictable conditions. All institutions in an economic system make up the institutional structure of that system". ${ }^{5}$ Apart from being a set of rules, institutions can have other various aspects, where they can be viewed as a set of normative rules. As the primary focus of this paper is placed on institutions as organizations operating within the public administration, then the institution is defined as a legal entity established for the purpose of permanent non-profit activities such as health, social care, culture, ed-

2 Jelena Budak and Marijana Sumpor, 'Nova institucionalna ekonomika i institucionalna konvergencija' (2009) 60 (3-4) Ekonomski pregled 168.

3 Douglass C North, Institucije, institucionalna promjena i ekonomska uspješnost (Masmedia 2003) 97.

4 Besides formal institutions there are informal institutions, that in definition by Lauth are institutions that are not formally codified in official documents. More about institutions and differences of formal and informal ones, see in: Hans-Joachim Lauth, 'Formal and Informal institutions in Jennifer Gandhi and Rubén Ruiz-Rufino (eds), Routledge Handbook of Comparative Political Institutions (Routledge 2015) 56-70.

5 Jasmin Halebić, 'Ekonomske institucije: nacionalni i globalni efekti' (2009) 10(2) Ekonomija/Economics 627 
ucation, science. ${ }^{6}$ Public administration is one of the strategically important areas, and the modernization of institutions operating in this area and the provision of fast and reliable public services are necessary components of a stimulating entrepreneurial environment and a prerequisite for ensuring a better standard of living for all citizens. ${ }^{7}$ It should be noted that public administration in terms of the State Administration System Act (NN 150/2011, 12/2013, 93/2016, 104/2016), the Act on the Organization and Scope of Ministries and Other Central State Administration Bodies (NN 93/2016, 104/2016, 116/2018), includes state administration bodies, bodies of local and regional self-government units and legal entities that have public authorities (public law bodies). ${ }^{8}$

Table 1. Public administration institutions in the Republic of Croatia

\begin{tabular}{|c|c|c|c|}
\hline & State Administration & $\begin{array}{l}\text { Local and regional } \\
\text { self-government }\end{array}$ & $\begin{array}{l}\text { Legal entities with } \\
\text { public powers }\end{array}$ \\
\hline \multirow{3}{*}{ Central level } & Ministries & & \multirow{7}{*}{$\begin{array}{l}\text { Agencies, } \\
\text { Institutions, } \\
\text { Funds, } \\
\text { Institutes, } \\
\text { Etc. }\end{array}$} \\
\hline & State Offices & & \\
\hline & State Administrative Organizations & & \\
\hline Regional level & State Administration Office & Counties & \\
\hline \multirow{3}{*}{ Local Level } & Regional Units & \multirow{3}{*}{$\begin{array}{l}\text { Cities and } \\
\text { Municipalities }\end{array}$} & \\
\hline & Branches & & \\
\hline & Regional Offices & & \\
\hline
\end{tabular}

Source: Author's review according to; State Administration System Act (NN 104/2016), Act on the Organization and Scope of Ministries and Other Central State Administration Bodies (NN 116/2018), Local and Regional Self-Government Act (NN 98/2019)

Institutions within the public administration of the Republic of Croatia operate at central, regional and local levels (Table 1 ). Their main task is to address the needs of society, to function on the basis of organizational structures, policies and programs, and to influence sustainable economic well-being, social cohesion, human well-being and social trust. ${ }^{9}$ Therefore it is clear that institutions can not only influence economic development by their actions, but it is also their duty to do so. Accordingly, the continuation of the paper is followed by describing an analysis of the relationship between economic development and state institutions.

6 Institucija, Hrvatska enciklopedija (Internet Edition 2021) <http://www.enciklopedija.hr/Natuknica.aspx?ID=27550> accessed 24 June 2020.

7 Strategija razvoja javne uprave za razdoblje od 2015. do 2020. godine = Public Administration Development Strategy for the period from 2015 to 2020 (NN 70/2015) (HR).

8 Ibid.

9 Bjorn Hallerod and others, 'Bad Governance and Poor Children: A Comparative Analysis of Government Efficiency and Severe Child deprivation in 68 low- and middle-income Countries' (2013) 48 World Development 19. 


\subsection{ECONOMIC DEVELOPMENT AND INSTITUTIONS INTERCONNECTEDNESS}

There is no single and generally accepted definition of economic development in the scientific literature. While economists in the 20th century viewed economic development primarily in terms of economic growth, sociologists viewed this concept in a broader sense and linked economic development to many other elements such as modernization and raising the quality of living standards. ${ }^{10}$ Economic development also includes improving institutional, social and political conditions - it is a concept that is broader than economic growth itself. ${ }^{11}$

Economic development theorists have come up with different definitions: i) in strictly economic categories, economic development traditionally means "the ability of a country's economy, whose initial economic situation has long been more or less static, to generate and maintain annual growth of its gross national income at a rate of $5 \%$ to $7 \%$ or more."; ${ }^{12}$ ii) taking into account its social component, it could be defined as "the development of a country's wealth for the benefit of its inhabitants, a sustainable increase in living standards that suggests an increase in per capita income, better education and better environmental protection." ${ }^{13}$ This development is based on the elimination of the main sources that inhibit freedom: poverty, tyranny, weak economic opportunities, systematic social scarcity, neglect of public capacities as well as intolerance or excessive activity of repressive states; ${ }^{14}$ iii) capital and technology are fundamental factors of economic development. However, although it is basically related to the economic structure, economic system and economic policy, the development of the economy means only the improvement of economic indicators. Factors such as health, education, life expectancy and literacy of the population are extremely important on the road to development. ${ }^{15}$

In accordance with the above, institutions can play a significant and key role in achieving the goals of economic development. According to Buterin, the role of institutions can be crucial, especially in transition countries that have been forced to reconstruct the whole concept of their economy and business system in a very short time. In doing so, some of the inherited institutions had a significant impact on the further concept of development. ${ }^{16}$ Carrying out the necessary reconstruction was not an easy task, especially with the fact that these are countries whose leadership for years belonged exclusively to one political option that created a kind of cult of personality focused on the leader. The collapse of such a one-party political system motivates citizens, guided by previous negative experiences, to give their trust to a diametrically opposite political optionin the first free elections. Such significant change brings with its a number of challenges, with the biggest challenge of economic recovery - to become competitive and export-oriented, to establish a new institutional framework for empowering

\footnotetext{
10 David Jaffee, Levels of Socio-economic Development Theory (2nd edn, Praeger 1998) 3.

11 Mate Babić, Ekonomija: uvod u analizu i politiku (Znanje 2011) 466.

12 Michael P Todaro and Stephen C Smith, Economic Development (8th edn, Addison-Wesley 2006) 14.

13 Jasmina Osmanković, Ekonomski razvoj - novi pristup (Ekonomski fakultet Sarajevo 2007) 111.

14 Jean Drèze and Amartya Sen, India: Development and Participation (OUP 2002) 20.

15 Paul A Samuelson and William D Nordhaus, Ekonomija (19th edn, Mate 2011) 521.

16 Vesna Buterin, 'Institucionalna promjena - čimbenik privlačenja investicija u zemljama tranzicije' (2015) 6(1) Praktični menadžment 30 .
} 
the legal, administrative and tax system in creating business environment, reducing unemployment and encouraging domestic and foreign investment. ${ }^{17}$ After long period of transition, a significant difference in the level of success in overcoming the mentioned challenges is visible: in creating a favorable business environment and encouraging domestic and foreign investment, while some still conduct businesses on the principle of acquaintances, with the presence of corruption and numerous administrative and other obstacles, which greatly slows economic growth and development. ${ }^{18}$ It is necessary to identify and develop the strong opportunities provided by the right institutional framework.

Institutions undoubtedly play an important role in increasing the functionality of society, especially economic efficiency. They are an integral part of social capital, as a key factor in economic growth and economic success. ${ }^{19}$ But the question of the relationship of the state and its institutions to the market in economic theory has been controversial for centuries, from A. Smith and his claim that the wealth of the nation stems from each individual's efforts to successfully achieve personal business goals, and thus create benefits for the wider community, ${ }^{20}$ to J. M. Keynes, an author who theoretically and practically proved that at a given moment and given circumstances, only meaningfully and complexly organized activity of the state and its institutions is able to establish a balance in the economy. ${ }^{21}$ Thus, the importance of the role of institutions in promoting economic efficiency and economic results is unquestionable, with the importance of measuring the quality of institutions, i.e. in the context of this paper, the quality of public administration, which can be expressed by quality indices of public administration.

\subsubsection{INSTITUTIONS QUALITY MEASUREMENT}

Until recently it was considered impossible to econometrically confirm the hypothesis that the quality of public governance affects economic development because the institution cannot be touched, felt, seen, or measured. ${ }^{22}$ One of relevant chosen study on quality management indices with respect to public administration can be seen in table 2 by Huther \& Shah (1998).

\footnotetext{
17 Ozren Božić, 'Razvoj europskih društvenih institucija te njihova obilježja u Hrvatskoj' (Institut za javne financije) <http://www. ijf.hr/institucionalizam/bozic.pdf> accessed 14 July 2020.

18 Buterin (n 16) 30.

19 Budak (n 2) 168.

20 Adam Smith, Bogatstvo naroda: istraživanje prirode i uzroka bogatstva naroda (Masmedia 1954) 52.

21 Mladen Vedriš and Ružica Šimić, 'Institucije, regulatorna uloga i gospodarski rast nacionalnih ekonomija' (2008) 21(1-2) Ekonomski vjesnik 9. 
Table 2. Public administration quality indices

\begin{tabular}{|l|l|}
\hline Index name & Index content \\
\hline Citizen Participation Index & $\begin{array}{l}\text { Political freedom } \\
\text { Political stability }\end{array}$ \\
\hline Government Orientation Index ${ }^{24}$ & $\begin{array}{l}\text { Legal system efficiency } \\
\text { Efficiency of bureaucracy } \\
\text { Absence of corruption }\end{array}$ \\
\hline Social Development Index & $\begin{array}{l}\text { Equal income distribution, Gini coefficient }{ }^{25} \\
\text { Human development (index) }\end{array}$ \\
\hline Economic Managment Index & $\begin{array}{l}\text { Central bank independence } \\
\text { Debt shares in GDP (debt-to-GDP-ratio) } \\
\text { International openness (trade policy) }\end{array}$ \\
\hline
\end{tabular}

Source: Author's review according to Anwar Shah and Jeff Huther, 'Applying a Simple Measure of Good Governance to the Debate on Fiscal decentralization' (1998) Policy Research Working Papers 3.

Although no index can cover all aspects of this complex issue, a focus on key areas of public administration can be useful in providing a comparative perspective on the difference in the quality of governance among different public administrations. They list four main quality management indices: Citizen Participation Index, Government Orientation Index, Social Development Index, and the quality index of government economic governance (Table 2).

These quality management indices aim is measuring the government's ability to provide quality public services on which the improvement of health and well-being of all citizens depends, as well as creation of positive climate for stable economic development. ${ }^{27}$ Bađun speaks of high correlation between constructed indices and GDP per capita, with following causality: if high quality of public administration results from high GDP per capita, then the quality index of public administration only reflects GDP per capita, were mentioned high correlation leads to the conclusion that the institutional aspect has an important role in economic growth as well as in development. ${ }^{28}$ On the EU institutional level quality of public administrations is also recognized as one of the important isuues. Therefore, Van Dooren in front of Euro-

23 According to Shah and Huther political freedom refers to the ability of citizens to influence the quality of the institutions whose services they receive, while political stability refers to the attractiveness to investors. See: Anwar Shah and Jeff Huther, 'Applying a Simple Measure of Good Governance to the Debate on Fiscal decentralization' (1998) Policy Research Working Papers 3-4 <https://doi.org/10.1596/1813-9450-1894> accessed 17 April 2021.

24 Government Orientation Indeks indicates the orientation towards the provision of public services, assessed through a total of three categories: judicial efficiency, bureaucracy efficiency and lack of corruption.

25 Shah (n 23) in economic terms define Gini coefficient (Gini index/Gini ratio) as the extent to which the distribution of income among individuals or households within the economy of a country deviates from a completely equal distribution

26 About Human Development Indeks see more in: United Nations Development Program, Human Development Report 1996 (Oxford University Press 1996) 123; According to Stanton it is a statistical tool used to measure the overall achievement of a country in its social and economic dimensions, which include human health, education levels and living standards. A country achieves a higher Human Development Index when life expectancy is longer, education levels are higher, and gross national income per capita is higher. See: Elizabeth A Stanton, The Human Development Index: A History (2007) Political Economy Research Institute, Workingpaper series no 127, 14-15 <https://scholarworks.umass.edu/cgi/viewcontent.cgi?article=1101\&context=peri_ workingpapers > accessed 17 September 2021.

27 Marijana Bađun, 'Kvaliteta javnog upravljanja i ekonomski rast: Hrvatska u kontekstu pridruživanja Europskoj uniji' (master thesis, Ekonomski fakultet Sveučilišta u Zagrebu 2005). 
pean Commission has made a feasibility study for better comparative indicators in the EU. The World Bank Governance Indicators ${ }^{29}$ are said to be the most widely used indicators for measuring public administration since 1996. According to the official page of World Bankthere are six dimensions of governance - Voice and Accountability, Political Stability and Absence of Violence, Government Effectiveness, Regulatory Quality, Rule of Law and Control of Corruption. The figure 1 according to the Van Dooren gives the scores of 27 EU member states on government effectiveness for the year 2016 with included confidence intervals - were a $90 \%$ confidence interval means that for measuring government effectiveness 100 times, the thrue value would be within the confidence interval in $90 \%$ of the cases. Besides this confidence intervals, a stricter $95 \%$ confidence interval was also used (Figure 1). ${ }^{30}$

Figure 1. Confidence intervals around the government effectiveness estimate

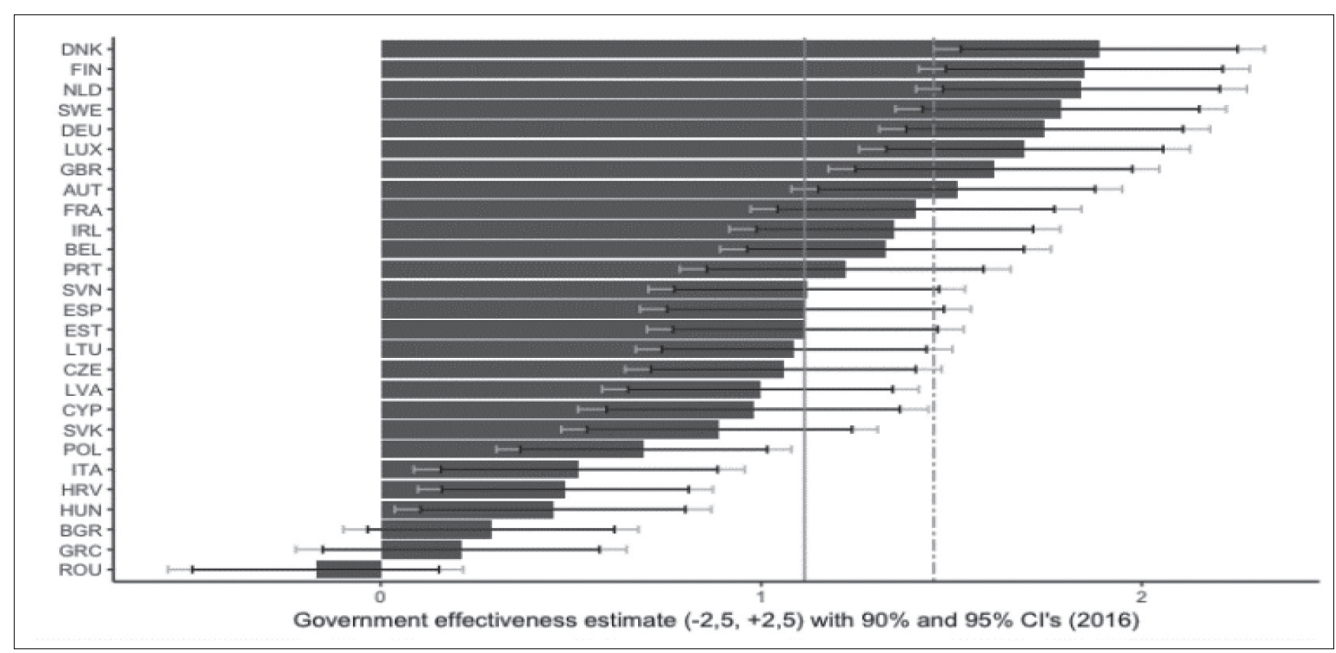

Source: Wouter Van Dooren, Measuring Public Administration: A Feasibility Study for Better Comparative Indicators in the EU (European Commission 2018) <https://doi.org/10.2767/819180> accessed 17 April 2021.

Taking into consideration estimated position of Croatian government effectiveness compared to other EU 27 countries in 2016, it is more than clear it is extremely important to present the state and the problems regarding institutions and its quality in Croatia. Beside other things, the aspect of weak institutional support to small and medium enterprises is given in the following chapter.

29 Van Dooren cites that: "Beyond international organisations (such as the World Bank, the World Economic Forum, and the OECD), also foundations (e.g. Bertelsmann), academic institutions (e.g. the University of Gothenburg and the Blavatnik School in Oxford) and consultancies (e.g. Gallup and companies providing risk assessments) have resorted to measuring public administration."

30 Wouter Van Dooren, Measuring Public Administration: A Feasibility Study for Better Comparative Indicators in the EU (European Commission 2018) <https://doi.org/10.2767/819180> accessed 17 April 2021. 


\section{REPUBLIC OF CROATIA CASE IN TERM OF INSTITUTIONS}

Modern societies presuppose institutions that are professional, socially responsible, independent of political influence, open to citizens, and effective. However, perception of institutions is as following - they are overly formalized, alienated and corrupt, and the media subject them to constant criticism. They are usually associated with unprofessionalism and the exchange of friendly services. ${ }^{31}$ Small and medium-sized enterprises operating in the Republic of Croatia are overburdened with administrative requirements and the time required in solving them. When high tax burden, legal uncertainty and lack of attention to the problems of citizens are added to this, it is clear that the lack of institutional support for small and medium enterprises is one of the key shortcomings in the institutions of the Republic of Croatia, which is a significant obstacle to economic development. ${ }^{32}$ In entrepreneurial activity, interaction with the environment is crucial, which can be stimulating or limiting for any phase of entrepreneurial activity: from the perception of opportunities and shaping intentions to starting a business. ${ }^{33}$ One of the main aspects of the entrepreneurial environment is institutional support of the state or government policy visible in the speed and ease of regulatory functioning. The Global Entrepreneurship Monitor (GEM), the world's largest survey of entrepreneurial activity, yields worrying results (Figure 2).

Figure 2. Global Entrepreneurship Monitor 2019/2020 Global Report

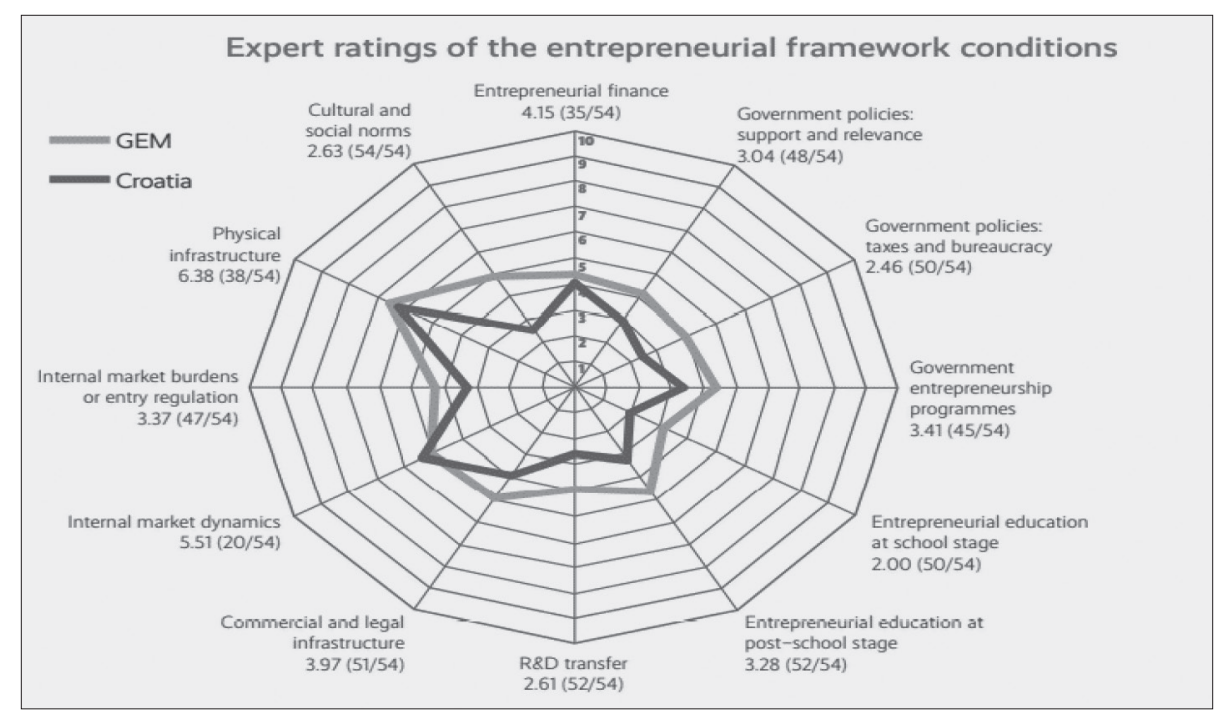

Source: Niels Bosma and others, Global Entrepreneurship Monitor: 2019/2020 Global Report (Global Entrepreneurship Research Association 2020).

31 Josip Kregar, 'Strategija razvitka Republike Hrvatske' (2001) 3(3-4) Hrvatska javna uprava 659.

32 Strategija razvoja poduzetništva u Republici Hrvatskoj 2013.-2020. = Entrepreneurship Development Strategy in the Republic of Croatia 2013-2020 (NN 136/2013) (HR).

33 Slavica Singer and others, Što čini Hrvatsku (ne)poduzetničkom zemljom?: GEM Hrvatska 2017 (CEPOR 2018) <http://www.cepor. hr/wp-content/uploads/2018/05/GEM-2017-za-web-FINAL.pdf> accessed 19 April 2021. 
According to Global Entrepreneurship Monitor 2019/2020 (2020) low innovative capacity of national small and medium enterprises has been identified as a long-term issue diminishing the country's competitiveness in international markets. There is also discrepancy between technological readiness of Croatian business and the share of new products with need to introduce new methods for supporting collaboration between research institutions and small and medium entreprises and in 2018 there has been an entrepreneurial voucher system introduced by the Croatian Agency for SMEs, Innovations and Investments (HAMAG-BICRO) ${ }^{34}$

National Entrepreneurship Context Index (NECI) as new GEM indicator, according to Singer et al. (2019) represents the estimated strenght of the national entrepreneurial framework within which entrepreneurial activity takes place at the individual level were 1 represents very poor entrepreneurial context while 10 presents very good entrepreneurial context. Therefore, NECI index in 2018 served for ranking of the countries involved in GEM research according to the criterion of the strenght of the entrepreneurial environment - which assesses how stimulating or restrictive the context is for entrepreneurial action. High ranked countries usually tend to have a higher quality of entrepreneurial activity - higher participation of people who recognize opportunities in their environment, higher share of started business ventures due to the perceived opportunity, more innovative business ventures etc. ${ }^{35}$

The results of the survey for the Republic of Croatia, which examines administrative barriers to entrepreneurship, legal regulation, institutional support for companies, tax burdens and tax policy, were evaluated for the year 2015 with a low score of 1.4 out of a possible 5.0, which placed the Republic of Croatia at the very bottom of the scale in relation to the countries of the European Union. ${ }^{36}$ It is evident, therefore, that the activities of the entrepreneurial environment in the Republic of Croatia are extremely restrictive.

The lack of institutional support is also addressed in the Global Economic Forum's Global Competitiveness Report 2019. The study measures national competitiveness of countries defined inbetween others as well of institutions, according to which Croatia is for $201963^{\text {rd }}$ out of 141 , while in category of institutions it achieved 77 out of 141 . Segments of institutional pillar that for 2019 were above $120^{\text {th }}$ place, pointing to devastating results were for the following segments - judicial independence, efficiency of legal framework in challenging regulations, public sector performance, burden of government regulation, efficiency of legal framework in settling disputes, government ensuring policy stability, government responsiveness to change, legal frameworks adaptability to digital business models and government long term vision. ${ }^{37}$ Taking in mind that some of earlier conducted research results ${ }^{38}$ speak of few categories listed as the one responsible for trust in institution and therefore instituonal miss-

34 Niels Bosma and others, Global Entrepreneurship Monitor: 2019/2020 Global Report (Global Entrepreneurship Research Association 2020) <https://www.gemconsortium.org/file/open?fileId=50443> accessed 18 April 2021.

35 Slavica Singer and others, Što čini Hrvatsku (ne)poduzetničkom zemljom?: GEM Hrvatska 2018 (CEPOR 2019) <http://www.cepor. hr/wp-content/uploads/2019/04/GEM2018zaweb.pdf> accessed 19 April 2021.

36 Ibid.

37 Klaus Schwab (ed), The Global Competitiveness Report 2019 (World Economic Forum 2019) <http://www3.weforum.org/docs/ WEF_TheGlobalCompetitivenessReport2019.pdf> accessed 22 April 2021.

38 See: Dubravka Jurlina Alibegović and Katarina Marošević, 'Institutional Trust in the Case of Croatian Regions' (2020) 36(34) Pravni vjesnik 25; Katarina Marošević, Regionalni razvoj i neravnoteže u Republici Hrvatskoj (Pravni fakultet Osijek 2021); Nataša Drvenkar, 'Reindustrijalizacija kao osnova strategije razvoja Panonske Hrvatske' (doctoral thesis, Ekonomski fakultet Sveučilišta u Osijeku 2012). 
functioning, in the upcoming chapter there are few of them listed as the main obstacles, since they appear in usual mentioning of institutional obstacles.

\subsection{INSTITUTIONAL DEVELOPMENT OBSTACLES}

Corruption is one of the main obstacles to the effective functioning of institutions. It presents the abuse of entrusted powers for private gain no matter what sector are we speaking of. ${ }^{39}$ Corruption unquestionably leads to a loss of citizens' trust in state government institutions; ${ }^{40}$ while the public sector is most exposed to corruption. ${ }^{41}$ In such a corrupt environment, institutions become powerless to carry out their core tasks, and the state becomes unsuccessful in creating the appropriate legal and economic regulations that form the basis of any institutional framework. ${ }^{42}$ Thus, public administration institutions, by their inadequate activities, significantly slow down the business cycle, and the judicial system, which should protect property rights and be one of the key pillars in a business venture. ${ }^{43}$

In general, the inefficiency of institutions in a corrupt society results in multiple harmful consequences that make the business environment unfavorable and everyday life difficult. ${ }^{44}$ Today, there are a number of standardized corruption surveys, including the Corruption Perceptions Index ${ }^{45}$ conducted by the Transparency International, whose main goal is to fight corruption both nationally and internationally. ${ }^{46}$ The 2020 survey provides worrying data. On a scale of 180 countries, according to the Corruption Perceptions Index, Croatia is in 63 out of 180 places with a total of 47 points. Some other Central and Eastern European Countries also share the bottom level in rank of corruption for 2020 - Hungary 44/100 and Romania $44 / 100 .^{47}$

There are certain measure more than welcome in fighting against corruption, for instance: 1) conduction of decisive measures - from adapting legal regulations to increasing transparency in the work of institutions ${ }^{48}$; 2) raising public awareness of the dangers and harms of

39 Jelena Budak, 'Korupcija u Hrvatskoj: percepcije rastu, problemi ostaju' (2006) 16(106) Privredna kretanja i ekonomska politika 67.

Tena Tarle, 'Korupcija u javnoj upravi' (2004) 38(79) Pravnik 129.

41 Vito Tanzi and Hamid Davoodi, 'Corruption, Public Investment, and Growth' (1997) Working Paper of International Monetary Fund <https://www.imf.org/external/pubs/ft/wp/wp97139.pdf〉 accessed 20 May 2020.

42 Vito Tanzi V, 'Corruption Around the World: Causes, Consequences, Scope, and Cures' (1998) 45(4) IMF Staff Papers 559 <https://www.imf.org/external/Pubs/FT/staffp/1998/12-98/tanzi.htm> accessed 12 May 2020.

43 Daniel Kaufmann and Shang-Jin Wei, 'Does “Grease Money” Speed Up the Wheels of Commerce?' (2000) IMF Working Papers No 00/64 〈https://www.imf.org/-/media/Websites/IMF/imported-full-text-pdf/external/pubs/ft/wp/2000/_wp0064.ashx> accessed 17 April 2021.

44 North (n 3).

45 The Corruption Perception Index of a certain country indicates the level of perception of corruption in the public sector on a scale from 0 to 100 represents a country that is perceived as highly corrupt, and it is rated 100 as a country completely free of corruption.

46 Corruption Perception Index for 2020 (Transparency International Croatia, 2020) <https://www.transparency.org/en/ countries/croatia> accessed 21 April 2021.

47 Ibid.

48 Slađana Aras, 'Korupcija' (2007) 41(84) Pravnik 25 
corruption, the need to combat it, but also the affirmation of citizens' rights because only in this way will citizens realize that corruption of institutions is not a tolerable phenomenon; ${ }^{49}$ 3) taking into account the responsibility of citizens as an addition to the responsibility of competent institutions as they are often the ones who agree to corrupt actions they even potentiate. $^{50}$

The sociological aspect of corruption, as stated by Piplica, should not be neglected. Namely, corruption is a common occurrence in transition countries and is a kind of catalyst in establishing market relations and serves as an instrument of social regulation in conditions of weak and disorganized public authorities. ${ }^{51}$ There is no doubt that the lack of legislation and numerous shortcomings in the system lead to a situation where compliance is more expensive than their circumvention, which is why they are one of the main reasons for the emergence of corruption. ${ }^{52}$ However, separate research indicates that a certain part of the responsibility lies with citizens who, despite the general condemnation of corruption, when it comes to their personal gain, show openness to corrupt practices.

Politization of institutions also frequently appears as an obstacle. The consequences of centralization and politization with authoritarian rule are clearly visible in its economy and society. An authoritative political values have led to putting democratic and legal values in the background. ${ }^{53}$ Over time, the need to develop a professional standard within institutions has become increasingly apparent. Professionalization means accepting candidates for jobs based on their competencies such as education, skills, and experience. Thus, the ability criterion becomes a fundamental criterion for admission to the public service and subsequent advancement during the service, which directly contributes to the efficiency and effectiveness of institutions. ${ }^{54}$ Likewise, professionalism presupposes that institutions are composed entirely of professionals and that political positions are reserved exclusively for the top in order to ensure the implementation of policies with a clear distinction between political and profes-

49 Tarle (n 40).

50 United Nations Office on Drugs and Crime, Corruption in Croatia: Bribery as Experienced bx the Population (UNODC 2011) < https://www.unodc.org/documents/data-and-analysis/statistics/corruption/Croatia_corruption_report_web_version.pdf> accessed 15 May 2020.

The mentioned source cites for the results of the research Corruption in Croatia - Real Corruption Experiences of Citizens, prepared by the United Nations Office on Drugs and Crime (UNODC) and the Zagreb Institute of Economics (EIZ) show that citizens offer bribes in as many as $58 \%$ of cases. Thus, in more than half of the cases, citizens themselves offer bribes, while in $40 \%$ of cases, bribes are given at the request of officials. In $8 \%$ of cases, the civil servant explicitly asks for a bribe, while in almost $28 \%$ of cases the civil servant implicitly lets the citizen know that a bribe needs to be given. Add to this the $4 \%$ of respondents who received a request through a third party as an intermediary and the complexity of corrupt practices becomes apparent. Besides, the answers of respondents who had experience with corruption and did not report it, it is amazing how large the percentage of those who perceive bribery as a positive practice is. As many as $24 \%$ of respondents equate corrupt practices with expressing gratitude, and $17 \%$ of them consider them a common practice. A quarter of the total number of respondents state that they have achieved personal gain based on corruption and that it therefore makes no sense to report it. Damir Piplica, 'Corruption and Inflation in Transition EU Member Countries' (2011) 20(2) Ekonomska misao i praksa 469.

52 Ministarstvo pravosuđa i uprave, 'Uzroci korupcije' (Ministarstvo pravosuđa i uprave) <https://mpu.gov.hr/uzrocikorupcije/21515> accessed 7 June 2020.

53 Ivan Koprić, 'Reforma javne uprave u Hrvatskoj: okviri, iskustva i perspektive' in X. Dnevi javnega prava (Inštitut za javno upravo 2004) 351-85.

54 Gordana Marčetić, 'Obrazovanje i usavršavanje javnih službenika u tranzicijskim zemljama' (2005) 12(2) Revija za socijalnu politiku 133. 
sional positions that cooperate with each other, but do not interfere in each other's work. ${ }^{55}$ In the Republic of Croatia, however, political interference in the daily work of institutions is considered almost common, which ensures quick progression of those who are obedient and capable. Such politicization demotivates educated, professional and impartial officials to perform their tasks effectively. The creation of a large number of unnecessary jobs, frequent reorganizations, and especially the favoring of political over professional criteria have caused apathy and demotivation. ${ }^{56}$ As professionalism is the foundation for the quality functioning of all institutions in the country, it is necessary to depoliticize by strengthening ethics, lowering the number of political positions and incorporating an adequate system of employment and promotion based on professional criteria rather than political suitability. Only in this way could the capacity of institutions solve problems efficiently, economically and for the benefit of all citizens be strengthened in the long run. ${ }^{57}$

Tax burden are the following obstacle often mentioned. Namely, the level of the tax burden, the simplicity of the tax system, the stability of tax regulations, the predictability of tax changes and the quality of tax administration and tax issues are sometimes decisive items defining a company's business path. ${ }^{58}$ Taxation can therefore serve as an important tool for building a just society and strong economy. Tax policy can strongly influence employment decisions, the level of investment and the willingness of entrepreneurs to expand their business. The tax system of the Republic of Croatia is characterized by many tax levies that stifle entrepreneurial business. The tax that stands out is the value added tax (VAT) whose rate of $25 \%$ is among the highest in Europe. Bašić emphasizes that SMEs are also hampered by the vagueness of certain provisions of tax regulations, the poor relationship between certain incentive measures and tax relief, which in some cases leads to their overlap or cancellation, and different tax treatment of taxpayers. ${ }^{59}$ Such a tax environment has a disincentive effect on entrepreneurs. Therefore, it is necessary to find space to reduce the overall tax burden on the economy, simplify the tax system and expand the tax base, which would largely remove obstacles to the development of entrepreneurship and ultimately have a positive impact on economic growth and development. ${ }^{60}$

High level of administrative obstacles and legal uncertainty can be seen in weak institutional support for SMEs. Those are for instance, the framework of the law, complexity of regulations and low-quality legal framework that place a significant burden on the business sector in creating value, hampering free access to the services market and stifling the potential for economic growth and job creation. ${ }^{61}$ The fact that smaller companies face disproportionately higher regulatory burdens than large enterprises is also worrying. ${ }^{62}$ Administrative duties and responsi-

55 Anamarija Musa, 'Javna uprava' in Jakša Barbić (ed), Hrvatski pravni sustav (Hrvatska akademija znanosti i umjetnosti 2012) 102-27.

56 Eugen Pusić (ed), Hrvatska država i uprava: stanje i perspektive (Hrvatska akademija znanosti i umjetnosti 2008).

57 Koprić (n 53).

58 Hrvoje Stojić (ed), Bijela knjiga (5th edn, Foreign Investors Council in Croatia 2017).

59 Ivan Bašić, Porezni menadžment (Ekonomski fakultet u Splitu 2017) 120.

60 Stojić (n 58).

61 Vlada Republike Hrvatske, Akcijski plan za administrativno rasterećenje gospodarstva (Vlada Republike Hrvatske 2019) 2.

62 Aleksander Aristovnik and Alka Obadić, 'The impact and efficiency of public administration excellence on fostering SMEs in EU countries' Amfiteatru Economic (2015) 17(39) 761. 
bilities are often identical for enterprises of all sizes, but small and medium-sized enterprises are less efficient in overcoming them. The reasons for the weaker ability to respond effectively to obstacles lie in the fact that small entrepreneurs are the ones who have to take care of administration and regulations in addition to the primary activity of the company, while large companies employ experts for this purpose. ${ }^{63}$ Thus, the vulnerability of small and medium enterprises is a central issue that needs to be addressed in order to improve the business climate and competitiveness, facilitate development and encourage job creation. ${ }^{64}$ In addition to the administrative burden, Croatian entrepreneurs also face legal uncertainty. Croatian legislation is characterized by too frequent amendments to laws and other regulations, each time due to some other norm that does not have the desired consequences or causes unforeseen costs, which introduces legal uncertainty into the business environment and leads to distrust of institutions. ${ }^{65}$ The situation was further aggravated by the Republic of Croatia joining the European Union. With the aim of adopting the legislation of the European Union, certain legal regulations had to be implemented in practice. Thus, Croatian entrepreneurs were adjusting their business to the relevant regulations of the European Union. Unfortunately, time pressure, lack of support from relevant institutions and the lack of adequate by laws to facilitate such adaptation have led to regulatory solutions that are difficult to implement in practice. ${ }^{66}$ Such complex operating conditions strictly impose the need to create means by which, in communication with the addressees to which the regulation will apply, it will be possible to predict the effects of this regulation on the ground, thus ensuring legal certainty as an essential precondition for any economic development. ${ }^{67}$ One such instrument is the assessment of the effects of the regulations. Regulatory impact assessment is a key tool for creating a high-quality, sustainable, and user-oriented legislative system through open, transparent, and active search for ways to solve problems and achieve set goals without creating additional administrative barriers for citizens and entrepreneurs. In other words, regulatory impact assessment is a decision-making tool, which analyzes the expected effects of proposed ways of solving problems with active communication of impact analysis with participants and stakeholders. ${ }^{68}$ In this regard, a legal framework for regulatory impact assessment consisting of the Law on Regulatory Impact Assessment [Zakon o procjeni učinaka propisa] (NN 44/2017) and the Decree on the Implementation of the Regulatory Impact Assessment Procedure [Uredba o provedbi postupka procjene učinaka propisa] (NN 52/2017) were made. ${ }^{69}$ Therefore, it is expected that as a direct effect of the application of this instrument, a better legal and administrative framework for economic operations and the exercise of citizens' rights will be achieved, as well as greater

63 Alka Obadić, 'Administrativne prepreke s kojima se suočavaju mala i srednja poduzeća na području zapošljavanja' (2018) 69(2) Ekonomski pregled 163.

64 Ibid.

65 Slavica Banić, 'Procjena učinka kao sredstvo poboljšanja kvalitete propisa i boljeg upravljanja' (2006) 6(4) Hrvatska i komparativna javna uprava 7.

66 Stojić (n 58).

67 Banić (n 65).

68 Vlada Republike Hrvatske, Izvješće o provedbi procjene učinaka propisa za razdoblje od 2013. do 2015. godine (Vlada Republike Hrvatske 2016) 4.

69 Vlada Republike Hrvatske, 'Zakonodavni okvir procjene učinaka propisa' (Vlada Republike Hrvatske, Ured za zakonodavstvo) <https://zakonodavstvo.gov.hr/procjena-ucinaka-propisa/zakonodavni-okvir-procjene-ucinaka-propisa/223> accessed 7 May 2020. 
legitimacy of political decisions, public policies and regulations. ${ }^{70}$ Since this is a relatively new institute, its real effects will be visible only after a certain time interval.

\section{INSTITUTIONAL SUPPORT OF THE PRIMARY SECTOR: FAMILIAL AGRICULTURAL HOLDINGS}

Contemporary foreign scientific literature is fruitful when speaking of the role of institutions in the development of agriculture. ${ }^{71}$ Concearning Croatia, agricultural economic importance although in decline, is relativly high. Agricultural sector plays an important role on the labour market since a significant percentage of the population lives from agriculture and earns its income from it. ${ }^{72}$ Franić et al. confirm that agriculture and food processing industry contribut with more than $9 \%$ in the total GDP, with more than $20 \%$ in total employment and with about $11 \%$ in total export and import, while in EU this mentioned sector has a little importance with a share of only about $1 \%$ in main economic indicators. Furthermore, the same author emphasize that although there are favourable natural resources, historical, organizational, economic and institutional reasons explain difficult situation in agriculture and in rural areas as well as the fear that considerable financial resources available for Croatian farmers, will not be adequately utilized. ${ }^{73}$ Unfortunately, within the primary economic sector in the Republic of Croatia there are certain examples of weak institutional support. Furthermore, parts of the Republic of Croatia that have a comparative advantage in agriculture, according to certain indicators, such as the development index, mainly represent some of the least developed parts of the Republic of Croatia (e.g. counties of Eastern Croatia). Thus, despite the advantages of the geographical area for agriculture as the main branch of the primary sector, large rates of economic growth and development are not recorded.

Reasons can be found in an extremely slow recovery of Croatian agriculture from transition difficulties, war events and problems related to agricultural land caused by the unsettled state of land registers and privatization. Additional burden is created by agricultural land ridden with land mines and the fact that cooperative organization in agriculture is still difficult due to bad experiences from the socialist period. ${ }^{74}$ Therefore, Croatian agriculture, faced with all these difficulties, needs quality help and support provided by the state and its institutions. That which is represented by small and medium-sized enterprises, which were discussed ear-

70 Anamarija Musa, 'Prilagodba procesa izrade propisa europskim integracijama: novine i izazovi' (2015) 6(1) Godišnjak Akademije pravnih znanosti Hrvatske 3.

71 Petro Putsenteilo and others, 'The Role of Institutions in the Development of Agriculture' (2020) 26(1) Bulgarian Journal of Agricultural Science 23; Thi Phuoc Lai Nguyen, Nitchakan Inkong and Nicolas Faysse, 'Role of Local Institutions in the Transition Towards Sustainable Agriculture: The Case Study of Thailand' in J. Casares Long (ed), Environmental Impact V (WIT Transactions on Ecology and the Environment vol 245, WITpress, 2020) 135-43 <https://doi.org/10.2495/EID200131> accessed 21 April 2021.

72 Concetta Civello, The agriculture sector in Croatia (Flanders, October 2012) <https://www.flandersinvestmentandtrade.com/ export/sites/trade/files/market_studies/2015-Croatia-Agriculture.pdf> accessed 22 April 2021.

73 Ramona Franić, Žaklina Jurišić and Ružica Gelo, 'Food Production and Rural Development: Croatian Perspective Within the European Context' (2014) 4(1) Agroeconomica Croatica 16. 
lier in the paper, for the development of the economy as a whole, are represented by small agricultural producers operating within family farms for the development of the primary sector. Therefore, it can be pointed out that within the primary sector, family farms are important drivers of economic activity.

"The agricultural holding is a fundamental and independent economic organizational unit in agriculture." The prefix family implies that it is "a family community of persons who live together and jointly spend their income to meet basic living needs, and are engaged in agricultural production or own agricultural property and share the means of production (machinery, facilities, land...)." 75 Family farms are an unbreakable link between the production of quality food, the preservation of rural areas and rural life and are crucial for economic growth and development at the local level - especially in rural areas. Economic motivation is complemented by social, cultural, traditional, and environmental reasons that further enrich the institute of family farms. For farmers working in small family farms, agriculture is not just a job but a way of life. Precisely because of this, they are closely linked to land, local territories, and regional identity ${ }^{76}$ which makes them an excellent material for economic recovery at the micro level. In this way, they coexist with nature and become guardians of tradition, they nurture and treat the space in which they live and work, and they are protective over said space. All this brings them a great advantage over large agricultural businesses whose only motive is to achieve the greatest possible profit. Many years of negligence towards small farmers and the absence of appropriate agricultural policy measures for the creation of economically viable family farms show that the institutions of the Republic of Croatia have not sufficiently recognized the potential of small family farms.

\subsection{SELECTED EXAMPLES OF IRREGULARITIES OF INSTITUTIONAL ACTIVITIES OF FAMILIAL AGRICULTURAL HOLDINGS}

The main factors reflecting insufficient institutional support for small family farms are evident in the following: inadequate legislative framework - primarily related to regulations governing the inheritance of agricultural land and rational use, fragmentation of land plots, unresolved property relations, relatively high share of state ownership in agricultural land, unfair distribution of state-owned agricultural land, inconsistency of cadaster and land registry data, undeveloped plots and underdeveloped infrastructure (roads, hydrotechnical, hydromelioration and agromelioration interventions). ${ }^{77}$ Most of these obstacles, therefore, are tied to agricultural land, which is not surprising because it is a necessary precondition for rational and profitable production. One of the main reasons for the unprofitability of Croatian agricultural production is fragmented land holdings that do not provide adequate conditions for profitable production. Family farms in the Republic of Croatia have an average size of 2.7 hectares and are fragmented into an average of 5.3 separate plots. Compared to most EU countries, agricul-

75 Petar Grahovec, 'Regionalne značajke posjedovne strukture u hrvatskoj poljoprivredi' (2006) 4(1) Zbornik Ekonomskog fakulteta u Zagrebu 23.

76 Derek McGlynn and others, 'Obiteljska poljoprivredna gospodarstva' (2013) 17 Revija ruralnog razvoja Europske unije <https:// enrd.ec.europa.eu/sites/enrd/files/PublicationENRDperiodical-17_hr.pdf〉 accessed 24 June 2020. 
tural holdings in the Republic of Croatia are six times smaller than the average size of agricultural land in most of those countries. Such fragmented agricultural land causes an increase in the costs of cultivation, sowing, protection and harvesting, which makes agricultural products more expensive and leads to non-competitiveness in the market. ${ }^{78}$ Therefore, the task of the competent institutions was to ensure the conditions for consolidation. The conditions are not provided due to the fact that the ownership relations have not been resolved. In addition, in the Republic of Croatia, data on agricultural land is kept in cadastral offices and land registry courts. Most of the data from these records are not synchronized, and the problem is the inaccuracy of data from the records in relation to the real situation. ${ }^{79}$

Furthermore, given the natural diversity of the Republic of Croatia, institutions should have approached each region in a way that best suits its characteristics and potential. With a regional approach, taking into account the natural peculiarities and thus the possibilities for a certain type of production, strategic planning, the Republic of Croatia should have determined the future production of food for its own needs. A balanced approach, as currently used, will not ensure a fair or purposeful allocation of resources, which is the most important and crucial factor for future agricultural production. ${ }^{80} \mathrm{~A}$ big problem for small family farms is the uneven distribution of direct subsidies. ${ }^{81}$ Namely, in the Republic of Croatia, approximately $10.2 \%$ of agricultural producers - among whom are exclusively representatives of large capital, and not small family farms - receive payments of more than 500,000 euros. Statistics show that such practices do not exist in other EU countries. The EU average in the group above 500,000 euros is only $2.9 \%$, while, for example, Austria has $0.3 \%$ in this category, the Netherlands only $0.2 \%$, and Ireland, Greece, Finland, Belgium, Luxembourg and Malta do not have a single producer receiving such high subsidies. ${ }^{82}$ It follows from the above that the Republic of Croatia, which is the smallest among these countries and with the weakest production, prefers a large accumulation of money to a smaller number of producers, which permanently endangers the business and survival of small farms.

Another example in which institutions give preference to large businesses to the detriment of small ones is visible in the area of agricultural land division, the importance of which for production has already been mentioned. Namely, the last disposal of state agricultural land took place in 2015 through a measure called Direct Allocation of Land to Landless Livestock Breeders [Direktne dodjele zemlje stočarima bez zemlje]. It resulted in the fact that $90 \%$ of the smallest farms in total received only $28 \%$ for use, and $1 \%$ or 8 large entities even $41 \%$ of the land. During the adoption of the measure, all proposals of the farmers' association were pointed out, which pointed to the injustice that would follow from the implementation of such a

78 Mira Ivković, Đuro Barković and Sanja Baćani, ‘Komasacija zemljišta i ruralni razvoj' (2010) 64(87) Geodetski list 297.

79 Ibid.

80 Ferdo Bašić, 'Regionalizacija hrvatske poljoprivrede za skladno uključivanje u zajedničku poljoprivrednu politiku EU' (2014) 1(1) Civitas Crisiensis 143.

81 Direct support includes measures under the Common Agricultural Policy of the European Union and state aid measures for payments in highly sensitive sectors and for the conservation of native and protected species and cultivation of agricultural plants. See: Ministarstvo poljoprivrede, 'Izravne potpore' (Ministarstvo poljoprivrede) <https://poljoprivreda.gov.hr/istaknuteteme/poljoprivreda-173/poljoprivredna-politika/mjere-poljoprivredne-politike/izravne-potpore/185> accessed 7 June 2020.

82 Author's calculation according to: Eurostat, Agriculture, forestry, and fishery statistics - 2019 edition (Publications Office of the European Union 2019). 
measure. ${ }^{83}$ Thus, the institutions, in this case the Ministry of Agriculture and the Agricultural Land Agency, once again showed insufficient care for small producers. All of the above causes a systematic shutdown of income-producing production, which is especially evident in the example of milk production as one of the most common items in the diet of citizens (Table 3).

Table 3. Comparison of cow milk delivery, (in t), 2009 and 2018

\begin{tabular}{|l|c|c|}
\hline & 2009 & 2018 \\
\hline Total quantity of delivered cow milk (t) & 675.289 & 453.023 \\
\hline
\end{tabular}

Source: Author's review according to: Izvještaji: Isporučene količine mlijeka za 2009. i 2018. godinu (Ministarstvo poljoprivrede) <https://hpa.mps.hr/jrdz-izvjestaji/isporucene-kolicine-mlijeka> accessed 15 June 2020.

Comparing the total amount of delivered cow's milk in 2009 with 2018, a significant decrease of 222,266 tons of milk is visible. In addition to milk, of course there are other industries with loss-making operations, which are offset by imports, leading to significant food dependence of the Republic of Croatia on imports from other countries (Table 4).

Table 4. Import and export of food and livestock, (000 HRK) for 2018 and 2019

\begin{tabular}{|l|c|c|}
\hline & 2018 & 2019 \\
\hline Import & 5499464 & 6387856 \\
\hline Export & 3276345 & 3811593 \\
\hline
\end{tabular}

Source: Author's review according to Croatian Bureau of Statistics, 'Foreign Trade in Goods of the Republic of Croatia - Provisional Data January - April 2019 and January - May 2019' (2019) 56(4.2.1/4) First Release <https://www.dzs.hr/Hrv_ Eng/publication/2019/04-02-01_04_2019.htm. Accessed26 May 2020> accessed 22 April 2021.

It is precisely this high and growing dependence on imports despite extremely favorable natural production conditions, the previous tradition of food self-sufficiency, and even the history of high exports in some livestock sectors, which is one of the key reasons for not only large trade deficit, but also for lagging economic growth and development. ${ }^{84}$ Croatian farmers according to the results of conducted research of Lončarić et al. for unfavorable situation in agriculture blame government and its ministries and at the same time expect the most improvement to be driven by government decisions. ${ }^{85}$

All of the above turns small farmers, instead of active market participants or producers who pay into the budget and thus encourage the creation of new value, into a kind of burden on the budget. Likewise, a large number of those who realized that there was no place for them in agricultural production left the rural area. Precisely in parts of the Republic of Croatia such

83 Udruga "Život” za opstanak OPG (Radio Osijek, 26 January 2015) <https://radio.hrt.hr/radio-osijek/clanak/udruga-zivot-zaopstanak-opg/82241/> accessed 7 June 2020.

84 Branko Salaj, 'Selo još uvijek čeka svoju priliku' (2013) 46(1) Hrvatska revija 6.

85 Ružica Lončarić, Zdenko Lončarić and Zrinka Tolušić, 'What Croatian Farmers Think About Situation in Agriculture?' (2016) 12(Special edition) European Scientific Journal 335 <https://eujournal.org/index. php/esj/article/view/7843> accessed 22 April 2021. 
as the counties of Eastern Croatia, which have the potential for agricultural production, this potential has not been used to a sufficient extent.

\section{CONCLUSION}

Research on institutions and institutional support has recently been significantly intensified. As institutions can be perceived as a set of rules of a game, it should be emphasized that the topic of this paper is to observe the activities of institutions in the form of organizations operating within the public administration. Within the aspect of activities and contributions in public administration, taking into account the associated permanent performance of non-profit activities - for example, health, social welfare, culture, education, science - there is a clear impact that institutions can have on economic development. The role of institutions can be of particular importance in transitional countries, due to the need for rapid restructuring of the economy and business in the transition from closed to open economy, but also a number of necessary accompanying changes. Certain countries made the transition relatively quickly, while some, such as the Republic of Croatia, had a significantly longer and slower process - while retaining certain barriers to this day - administrative barriers, a high share of corrupt practices and activities, the principle of business with acquaintances, etc. Institutional segments which are connected to extremely low levels by most indicators are judicial independence, efficiency of legal framework in challenging regulations, public sector performance, burden of government regulation, efficiency of legal framework in settling disputes, government ensuring policy stability, government responsiveness to change, legal frameworks adaptability to digital business models and government long term vision. However, changes in the way institutions operate and work can certainly make a turnaround. Therefore, the capacity of institutions must not be neglected, and measuring the quality of institutions, i.e. the quality of public administration is one of the ways to record changes. The future research should definitely take into account adequate empirical analysis with tracked changes in trends of chosen indicators responsible for quality of institutions measuring.

Institutional support to small and medium enterprises as potential drivers of economic growth and development in the Republic of Croatia is characterized by certain negatives that accompany the work of institutions, such as politicization, corruption, administrative barriers, tax burdens and legal uncertainty, therefore one can rightfully assume that clear and undoubted institutional support is lacking. Such weak support consequently leads to a negative impact on economic development. However, apart from the obstacles faced by entrepreneurs, the role and place of family farms within the primary sector is characterized by intricate business bureaucracy, unsettled land registers and privatization, non-support and misunderstanding by those whose primary goal should be community welfare, framework, unresolved property and legal relations, unfair distribution of state-owned agricultural land and state aid, which makes the environment unsafe for production, investment and future planning. Therefore, family farms generally remain in the shadow of large corporate systems that are often favored by the competent institutions. Members of family farms do not only work in agriculture, they live agriculture, so we can also consider them a kind of guardians of tradition and customs. However, given the numerous prominent obstacles, today's rural areas 
mostly become, or remain, empty. Therefore, the entire Republic of Croatia, and especially the associated counties of Eastern Croatia and areas in which the activities of the primary sector are more represented, need a strong shift in the field of operation and work of institutions and the realization of institutional support. Only then can progress be expected at local, regional and national levels.

\section{BIBLIOGRAPHY}

1. - - Institucija, Hrvatska enciklopedija (Internet Edition, 2021) <http://www.enciklopedija.hr/ Natuknica.aspx?ID=27550> accessed 24 June 2020

2. Aras S, 'Korupcija' (2007) 41(84) Pravnik 25

3. Aristovnik A and Obadić A, 'The impact and efficiency of public administration excellence on fostering SMEs in EU countries' (2015) 17(39) Amfiteatru Economic 761

4. Babić M, Ekonomija: uvod u analizu i politiku (Znanje 2011)

5. Bađun M, 'Kvaliteta javnog upravljanja i ekonomski rast: Hrvatska u kontekstu pridruživanja Europskoj uniji' (master thesis, Ekonomski fakultet Sveučilišta u Zagrebu 2005)

6. Banić S, 'Procjena učinka kao sredstvo poboljšanja kvalitete propisa i boljeg upravljanja' (2006) 6(4) Hrvatska i komparativna javna uprava 7

7. Bašić $\mathrm{F}$, 'Regionalizacija hrvatske poljoprivrede za skladno uključivanje u zajedničku poljoprivrednu politiku EU’ (2014) 1(1) Civitas Crisiensis 143

8. Bašić I, Porezni menadžment (Ekonomski fakultet u Splitu 2017)

9. Bosma N and others, Global Entrepreneurship Monitor: 2019/2020 Global Report (Global Entrepreneurship Research Association 2020) <https://www.gemconsortium.org/file/open?fileId=50443> accessed 18 April 2021

10. Budak J and Sumpor M, 'Nova institucionalna ekonomika i institucionalna konvergencija' (2009) 60(3-4) Ekonomski pregled 168

11. Budak J, 'Korupcija u Hrvatskoj: percepcije rastu, problemi ostaju' (2006) 16(106) Privredna kretanja i ekonomska politika 67

12. Buterin $\mathrm{V}$, 'Institucionalna promjena - čimbenik privlačenja investicija u zemljama tranzicije’ (2015) 6(1) Praktični menadžment 30

13. Civello C, The agriculture sector in Croatia (Flanders, October 2012) <https://www.flandersinvestmentandtrade.com/export/sites/trade/files/market_studies/2015-Croatia-Agriculture.pdf > accessed 22 April 2021

14. Croatian Bureau of Statistics, 'Foreign Trade in Goods of the Republic of Croatia - Provisional Data January - April 2019 and January - May 2019' (2019) 56(4.2.1/4) First Release <https://www.dzs. hr/Hrv_Eng/publication/2019/04-02-01_04_2019.htm. Accessed26 May 2020> accessed 22 April 2021

15. Drèze J and Sen A, India: Development and Participation (OUP 2002)

16. Drvenkar N, 'Reindustrijalizacija kao osnova strategije razvoja Panonske Hrvatske' (doctoral thesis, Ekonomski fakultet Sveučilišta u Osijeku 2012)

17. Eurostat, Agriculture, forestry, and fishery statistics - 2019 edition (Publications Office of the European Union 2019) 
18. Franić R, Jurišić Ž and Gelo R, 'Food Production and Rural Development: Croatian Perspective Within the European Context' (2014) 4(1) Agroeconomica Croatica 16

19. Grahovec P, 'Regionalne značajke posjedovne strukture u hrvatskoj poljoprivredi' (2006) 4(1) Zbornik Ekonomskog fakulteta u Zagrebu 23

20. Halebić J, 'Ekonomske institucije: nacionalni i globalni efekti' (2009) 16(2) Ekonomija/Economics 627

21. Hallerod B and others, 'Bad Governance and Poor Children: A Comparative Analysis of Government Efficiency and Severe Child deprivation in 68 low- and middle-income Countries' (2013) 48 World Development 19

22. Ivković M, Barković Đ and Baćani S, 'Komasacija zemljišta i ruralni razvoj’ (2010) 64(87) Geodetski list 297

23. Jaffee D, Levels of Socio-economic Development Theory (2nd edn, Praeger 1998)

24. Jurlina Alibegović D and Marošević K, 'Institutional Trust in the Case of Croatian Regions' (2020) 36(3-4) Pravni vjesnik 25

25. Kaufmann D and Wei S, 'Does "Grease Money" Speed Up the Wheels of Commerce?' (2000) IMF Working Papers No 00/64 <https://www.imf.org/-/media/Websites/IMF/imported-full-text-pdf/ external/pubs/ft/wp/2000/_wp0064.ashx> accessed 17 April 2021

26. Koprić I, 'Reforma javne uprave u Hrvatskoj: okviri, iskustva i perspektive' in X. Dnevi javnega prava (Inštitut za javno upravo 2004) 351-85

27. Kregar J, 'Strategija razvitka Republike Hrvatske' (2001) 3(3-4) Hrvatska javna uprava 659

28. Lauth HJ, 'Formal and Informal institutions in Jennifer Gandhi and Rubén Ruiz-Rufino (eds), Routledge Handbook of Comparative Political Institutions (Routledge 2015) 56-70

29. Lončarić R, Lončarić $Z$ and Tolušić $Z$, 'What Croatian Farmers Think About Situation in Agriculture?' (2016) 12(Special edition) European Scientific Journal $335<$ https://eujournal.org/index. php/esj/article/view/7843> accessed 22 April 2021

30. Marčetić G, 'Obrazovanje i usavršavanje javnih službenika u tranzicijskim zemljama' (2005) 12(2) Revija za socijalnu politiku 133

31. Marošević K, Regionalni razvoj i neravnoteže u Republici Hrvatskoj (Pravni fakultet Osijek 2021)

32. McGlynn D and others, 'Obiteljska poljoprivredna gospodarstva' [2013] 17 Revija ruralnog razvoja Europske unije <https://enrd.ec.europa.eu/sites/enrd/files/PublicationENRDperiodical-17_ hr.pdf> accessed 24 June 2020

33. Musa A, 'Javna uprava' in Jakša Barbić (ed), Hrvatski pravni sustav (Hrvatska akademija znanosti i umjetnosti 2012) 102-27

34. Musa A, 'Prilagodba procesa izrade propisa europskim integracijama: novine i izazovi' (2015) 6(1) Godišnjak Akademije pravnih znanosti Hrvatske 3

35. Nguyen TPL, Inkong N and Faysse N, 'Role of Local Institutions in the Transition Towards Sustainable Agriculture: The Case Study of Thailand' in J. Casares Long (ed), Environmental Impact V (WIT Transactions on Ecology and the Environment vol 245, WITpress, 2020) 135-43 <https://doi. org/10.2495/EID200131> accessed 21 April 2021

36. North DC, 'Economic Performance Through Time' (1994) 84(3) The American Economic Review 359

37. North DC, Institucije, institucionalna promjena i ekonomska uspješnost (Masmedia 2003)

38. Obadić A, 'Administrativne prepreke s kojima se suočavaju mala i srednja poduzeća na području zapošljavanja' (2018) 69(2) Ekonomski pregled 163

39. Osmanković J, Ekonomski razvoj - novi pristup (Ekonomski fakultet Sarajevo 2007) 
40. Piplica D, 'Corruption and Inflation in Transition EU Member Countries' (2011) 20(2) Ekonomska misao i praksa 469

41. Puljiz V, Ravlić S and Visković V (eds), Hrvatska u EU: Kako dalje? (Centar za demokraciju i pravo Miko Tripalo 2012)

42. Pusić E (ed), Hrvatska država i uprava: stanje i perspektive (Hrvatska akademija znanosti i umjetnosti 2008)

43. Putsenteilo P and others, 'The Role of Institutions in the Development of Agriculture' (2020) 26(1) Bulgarian Journal of Agricultural Science 23

44. Salaj B, 'Selo još uvijek čeka svoju priliku' (2013) 46(1) Hrvatska revija 6

45. Samuelson PA and Nordhaus WD, Ekonomija (19th edn, Mate 2011)

46. Schwab K (ed), The Global Competitiveness Report 2019 (World Economic Forum 2019) <http:// www3.weforum.org/docs/WEF_TheGlobalCompetitivenessReport2019.pdf> accessed 22 April 2021

47. Shah A and Huther J, 'Applying a Simple Measure of Good Governance to the Debate on Fiscal decentralization' (1998) Policy Research Working Papers <https://doi.org/10.1596/1813-94501894> accessed 17 April 2021

48. Singer S and others, Što čini Hrvatsku (ne)poduzetničkom zemljom?: GEM Hrvatska 2017 (CEPOR 2018) <http://www.cepor.hr/wp-content/uploads/2018/05/GEM-2017-za-web-FINAL.pdf〉 accessed 19 April 2021

49. Singer S and others, Što čini Hrvatsku (ne)poduzetničkom zemljom?: GEM Hrvatska 2018 (CEPOR 2019) 〈http://www.cepor.hr/wp-content/uploads/2019/04/GEM2018zaweb.pdf〉 accessed 19 April 2021

50. Smith A, Bogatstvo naroda: istraživanje prirode i uzroka bogatstva naroda (Masmedia 1954)

51. Stanton EA, The Human Development Index: A History (2007) Political Economy Research Institute, Workingpaper series no 127 <https://scholarworks.umass.edu/cgi/viewcontent.cgi?article=1101\&context=peri_workingpapers $>$ accessed 17 September 2021

52. Stojić H (ed), Bijela knjiga (5th edn, Foreign Investors Council in Croatia 2017)

53. Tanzi V and Davoodi H, 'Corruption, Public Investment, and Growth' (1997) Working Paper of International Monetary Fund <https://www.imf.org/external/pubs/ft/wp/wp97139.pdf> accessed 20 May 2020

54. Tanzi V, 'Corruption Around the World: Causes, Consequences, Scope, and Cures' (1998) 45(4) IMF Staff Papers 559 <https://www.imf.org/external/Pubs/FT/staffp/1998/12-98/tanzi.htm> accessed 12 May 2020

55. Tarle T, 'Korupcija u javnoj upravi' (2004) 38(79) Pravnik 129

56. Todaro MP and Smith SC, Economic Development (8th edn, Addison-Wesley 2006)

57. United Nations Development Program, Human Development Report 1996 (Oxford University Press 1996)

58. United Nations Office on Drugs and Crime, Corruption in Croatia: Bribery as Experienced bx the Population (UNODC 2011) < https://www.unodc.org/documents/data-and-analysis/statistics/corruption/Croatia_corruption_report_web_version.pdf> accessed 15 May 2020

59. Van Dooren W, Measuring Public Administration: A Feasibility Study for Better Comparative Indicators in the EU (European Commission 2018) <https://doi.org/10.2767/819180> accessed 17 April 2021

60. Vedriš M and Šimić R, 'Institucije, regulatorna uloga i gospodarski rast nacionalnih ekonomija' (2008) 21(1-2) Ekonomski vjesnik 9

61. Zmaić K, 'Agrarna ekonomika' (2002) 8(2) Poljoprivreda 57 


\section{REGULATIONS AND DOCUMENTS}

1. Strategija razvoja javne uprave za razdoblje od 2015. do 2020. godine = Public Administration Development Strategy for the period from 2015 to 2020 (NN 70/2015) (HR)

2. Strategija razvoja poduzetništva u Republici Hrvatskoj 2013.-2020. = Entrepreneurship Development Strategy in the Republic of Croatia 2013-2020 (NN 136/2013) (HR)

3. Vlada Republike Hrvatske, Akcijski plan za administrativno rasterećenje gospodarstva (Vlada Republike Hrvatske 2019) (HR)

4. Vlada Republike Hrvatske, Izvješće o provedbi procjene učinaka propisa za razdoblje od 2013. do 2015. godine (Vlada Republike Hrvatske 2016) (HR)

\section{INTERNET SOURCES}

1. - - Corruption Perception Index for 2020 (Transparency International Croatia, 2020) <https:// www.transparency.org/en/countries/croatia> accessed 21 April 2021

2. - - Izvještaji: Isporučene količine mlijeka za 2009. i 2018. godinu (Ministarstvo poljoprivrede) <https://hpa.mps.hr/jrdz-izvjestaji/isporucene-kolicine-mlijeka> accessed 15 June 2020

3. - - Udruga “Život” za opstanak OPG (Radio Osijek, 26 January 2015) <https://radio.hrt.hr/radio-osijek/clanak/udruga-zivot-za-opstanak-opg/82241/> accessed 7 June 2020.

4. - - Vrijednosti indeksa razvijenosti i pokazatelja za izračun indeksa razvijenosti 2018 (Ministarstvo regionalnog razvoja i fondova Europske unije, 5 January 2018) <https://razvoj.gov.hr/o-ministarstvu/ djelokrug-1939/regionalni-razvoj/indeks-razvijenosti/vrijednosti-indeksa-razvijenosti-i-pokazatelja-za-izracun-indeksa-razvijenosti-2018/3740> accessed 21 April 2021

5. Božić O, 'Razvoj europskih društvenih institucija te njihova obilježja u Hrvatskoj' (Institut za javne financije) <http://www.ijf.hr/institucionalizam/bozic.pdf> accessed 14 July 2020

6. Ministarstvo poljoprivrede, 'Izravne potpore' (Ministarstvo poljoprivrede) <https://poljoprivreda. gov.hr/istaknute-teme/poljoprivreda-173/poljoprivredna-politika/mjere-poljoprivredne-politike/ izravne-potpore/185> accessed 7 June 2020.

7. Ministarstvo pravosuđa i uprave, 'Uzroci korupcije' (Ministarstvo pravosuđa i uprave) <https://mpu. gov.hr/uzroci-korupcije/21515> accessed 7 June 2020.

8. Vlada Republike Hrvatske, 'Zakonodavni okvir procjene učinaka propisa' (Vlada Republike Hrvatske, Ured za zakonodavstvo) <https://zakonodavstvo.gov.hr/procjena-ucinaka-propisa/zakonodavni-okvir-procjene-ucinaka-propisa/223> accessed 7 May 2020 


\section{INSTITUCIJE I EKONOMSKI RAZVOJ - TEORIJSKA PERSPEKTIVA PROPUŠTENE INSTITUCIONALNE PODRŠKE U REPUBLICI HRVATSKOJ}

\section{Sažetak}

Djelovanje institucija pokazalo se iznimno važnim u ostvarenju gospodarskog rasta i razvoja nacionalnih gospodarstava. Osim toga, uočene neravnoteže unutar nacionalnog gospodarstva mogu se minimizirati zahvaljujući doprinosu institucija. Stoga je potrebno otkriti prilike i aktivnosti koje bi uz primjenu adekvatne institucionalne implementacije, mogle potaknuti razvoj određenog područja. U Republici Hrvatskoj postoji niska razina poticajnog okruženja za mala i srednja poduzeća kao jednog od pokretača gospodarstva. Osim toga, dijelovi Republike Hrvatske u kojima prevladava primarni sektor generalno su znatno manje razvijeni (primjerice, županije istočne Hrvatske). Stoga je cilj ovoga rada ispitati ulogu i važnost institucija u gospodarskomu razvoju. Također, cilj je otkriti i opisati institucionalne zapreke u promicanju malog i srednjeg poduzetništva te prikazati odabrane primjere promašene institucionalne promocije unutar primarnog sektora, kao gospodarske grane najzastupljenije u dijelovima Republike Hrvatske čiji je razvoj znatno niži od prosjeka ili čak najniži.

$\mathrm{U}$ radu se pretežno koriste teorijske deskriptivne metode potkrijepljene dodatnim podacima kako bi se potvrdilo postojanje navedenih zapreka unutar malog i srednjeg poduzetništva te primarnog sektora.

Ključne riječi: institucije, ekonomski razvoj, primarni sektor, Republika Hrvatska

\section{(c) (1) (\$)}

This work is licensed under a Creative Commons

Attribution-NonCommercial 4.0 International License.

* Dr. sc. Katarina Marošević, docentica Pravnog fakulteta Sveučilišta Josipa Jurja Strossmayera u Osijeku, S. Radića 13, 31000 Osijek. E-adresa: katarina.marosevic@pravos.hr. ORCID: https://orcid.org/0000-0002-8727-130X.

** Lorela Vukovac, mag. iur. E-adresa: lorela.vukovac@gmail.com. ORCID: https://orcid.org/0000-0001-7872-1308. 